\title{
JPAK
}

Vol. 1, Tahun ke-1, April 2009

ISSN; 2085-0743

Memahami dan Memanfaatkan Penelitian dalam Karya-Karya Keagamaan Prof.Dr.John Tondowidjojo, CM

Dasar Pelayanan dan Tujuan Pelayanan Pastoral Gereja Drs. DB. Karnan Ardijanto, $\mathrm{MA}, \mathrm{Pr}$.

Praktek Hidup. Keagamaan Blaize Pascal: Antara Ateisme dan Teisme (Refleksi Kritis Partial Terhadap

Praktek Hidup Keagamaan Manusia Modern) Hipolitus K Kewuel, S.Ag, M.Hum

Ménumbuhkan Kerukunan dalam Hidup Beragama Menurut Pandangan Agama Katolik Suparto, S.Ag, M.Pd.

Musik Kateketis : Alternatif Menjadikan Katekese Lebih

Menarik Aloysius Suhardi, S.Pd

Model Pembelajaran Kooperatif sebagai Salah Satu Alternative dalam Proses Pembelajaran Pendidikan Agama Katolik di

Sekolah Gabriel Sunyoto, S.Pd

\section{Lembaga Penelitian}

Sekolah Tinggi Keguruan dan IImu Pendidikan Teologi Katolik "Widya Yuwana" 


\title{
JPAK \\ JURNAL PENDIDIKAN AGAMA KATOLIK
}

Jurnal Pendidikan Agama Katolik (JPAK) adalah media komunikasi ilmiah yang dimaksudkan untuk mewadahi hasil penelitian, hasil studi, atau kajian ilmiah yang berkaitan dengan Pendidikan Agama Katolik sebagai salah satu bentuk sumbangan STKIP Widya Yuwana Madiun bagi pengembangan Pendidikan Agama Katolik pada umumnya.

\section{Penasehat}

Ketua Yayasan Widya Yuwana Madiun

\author{
Pelindung \\ Ketua STKIP Widya Yuwana Madiun
}

Penyelenggara

Lembaga Penelitian STKIP Widya Yuwana Madiun

Ketua Penyunting

Hipolitus Kristoforus Kewuel, S.Ag, M.Hum

Penyunting Pelaksana

Hardi Aswinarno, MA, Pr

Drs. DB. Karnan Ardijanto, MA, Pr

Penyunting Ahli

Prof. Dr. Tondowidjojo, CM

Dr. Ola Rongan Wilhelmus, SF, MS

Dr. Armada Riyanto, CM

Sekretaris

Gabriel Sunyoto, S.Pd

\section{Alamat Redaksi}

STKIP Widya Yuwana

Jln. Mayjend Panjaitan. Tromolpos: 13. Telp. 0351-463208. Fax. 0351-483554 Madiun 63102 - Jawa Timur - Indonesia

Jurnal Pendidikan Agama Katolik (JPAK) diterbitkan oleh Lembaga Penelitian, STKIP Widya Yuwana Madiun. Terbit 2 kali setahun (April dan Oktober).

Terbit Perdana: April 2009 

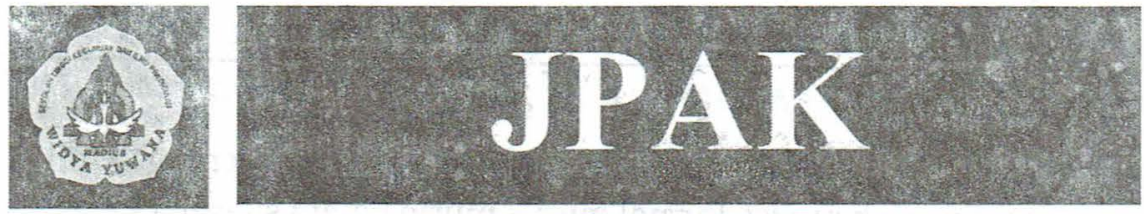

Vol. 1, Tahun ke-1, April 2009

ISSN; 2085-0743

\section{DAFTAR ISI}

\section{Editorial}

03 Memahami dan Memanfaatkan Penelitian dalam KaryaKarya Keagamaan

Prof. Dr. John Tondowidjojo, CM

09 Dasar dan Tujuan Pelayanan Petugas Pastoral Gereja Drs. DB. Karnan Ardijanto, $M A, P r$

22 Praktek hidup keagamaan Blaize Pascal: Antara Ateisme dan Teisme (Refleksi Kritis Partial terhadap Praktek Hidup Keagamaan Manusia Modern)

Hipolitus K Kewuel, S.Ag., M.Hum.

34 Menumbuhkan Kerukunan dalam Hidup Beragama Menurut Pandangan Agama Katolik

Suparto, S.Ag.

41 Musik Kateketis : Alternatif Menjadikan Katekese Lebih Menarik

Aloysius Suhardi, S.Pd.

57 Model Pembelajaran Kooperatif sebagai Salah Satu Alternative dalam Proses Pembelajaran Pendidikan Agama Katolik di Sekolah

Gabriel Sunyoto, S.Pd. 


\title{
DASAR DAN TUJUAN PELAYANAN PETUGAS PASTORAL GEREJA
}

\author{
Drs. DB. Karnan Ardijanto, MA, Pr \\ Sekolah Tinggi Keguruan dan Imu Pendidikan Agama Katolik \\ (STKIP) Widya Yuwana Madiun
}

\begin{abstract}
Every Catholic is called and sent to continue Christ's mission in union with the Church. To realize her/his call, $s(h e)$ participates in pastoral ministries of local Church. In fact, most of them participate in pastoral ministries is not based on true motivation. This article wants to challenge pastoral ministers to purify their fundamental motivation in order to nourish the Mystic Body of Christ. It also suggests them to cooperate with each other in their pastoral ministries.
\end{abstract}

Key Words : Alasan Dasar, Pelayanan Pastoral dan Pelayan Pastoral, Sakramen Baptis dan Krisma, Sakramen Tahbisan, Kerjasama

\section{Pendahuluan}

Setelah kenaikanNya ke surga, Yesus Kristus mengutus Gereja untuk melanjutkan karyaNya di dunia. Karya perutusan ini diperuntukkan bagi seluruh Gereja, tidak terbatas pada para rasul saja. Dalam mewujudkan perutusannya, Gereja mengundang seluruh anggotanya untuk ikut ambil bagian, khususnya para petugas pastoral Gereja, baik mereka yang ditahbiskan (uskup, imam, dan diakon) maupun mereka yang tidak ditahbiskan (katekis, suster, bruder, pengurus dewan paroki, ketua lingkungan, dan lain-lain).

Gereja Indonesia saat ini dapatlah dikatakan sebagai "Gereja Umat", tingkat partisipasi kaum awam yang mengagumkan dalam kehidupan Gereja (KWI, 2007: 81-82; bdk. Gonzalez, 1998: 6-7). Namun di lain pihak harus juga diakui bahwa tidaklah selalu mudah untukmengajak umat 
beriman melibatkan diri dalam karya-karya Gereja. Mereka cenderung menolak dengan berbagai alasan: sibuk, tak punya waktu, anak-anak masih kecil, karir di kantor bisa terganggu, tidak pantas, tidak mampu atau bukan bidang keahliannya, dan sebagainya (Thress, 2001:30-31).

Realita ini mengantar pada persoalan: apakah kemampuan/keahlian dan kepantasan diri seseorang yang mendorong mereka terlibat atau tidak terlibat dalam karya Gereja? Apakah mereka yang terlibat dalam karya Gereja adalah para pengangguran atau pensiunan saja? Apakah mereka yang ikut serta dalam karya Gereja adalah mereka yang memiliki anak sudah akil balig? Kiranya tidaklah demikian. Kalau begitu, apakah yang menjadi dasar (raison d'etre) keterlibatan para petugas pastoral tersebut dalam keseluruhan karya pelayanan pastoral Gereja? Dan apa pula tujuan pelayanan mereka?

Memahami dasar dan tujuan pelayanan para petugas pastoral tentu membantu para petugas pastoral sendiri untuk semakin mantap dalam pelayanan pastoral mereka serta diharapkan memberikan motivasi yang lebih baik dalam tugas pelayanan mereka sehari-hari.

\section{Pelayanan Pastoral Gereja}

Di dalam Gereja ada keanekaragaman pelayanan, tetapi dalam kesatuan perutusan yang diterima dari Kristus, sekaligus memiliki satu tujuan (AA2): pembangunan Tubuh Kristus dan pembangunan Kerajaan Allah di dunia.

Pelayanan pastoral merupakan suatu bentuk pelayanan keselamatan bagi manusia dalam Gereja; mendapat wujudnya di dalam Gereja. Gereja merupakan wadah sekaligus jalan di mana keselamatan masuk ke dalam kehidupan manusia. Dengan demikian melalui pelayanan pastoralNya yang diwujudkan dalam berbagai bentuk aktifitas dan cara, Gereja mewartakan, mengaktualisasikan, mengkomunikasikan anugerah keselamatan Allah bagi manusia dalam hidup manusia. Dengan kata lain, Gereja mengusahakan pertumbuhan, perkembangan dan pemekaran Tubuh Kristus, sekaligus mewujudkan Kerajaan Allah dan meluaskannya sampai ia mencapai kepenuhannya pada akhir jaman (LG 9).

Pelaksanaan pelayanan pastoral Gereja merupakan hak dan tanggung jawab seluruh Gereja (AA 2). Gereja adalah subjek pelaksanaan pelayanan pastoral itu. Akan tetapi pelaksanaan pelayanan pastoral Gereja ini secara khusus dan nyata dipercayakan Gereja kepada para petugas 
pastoralnya. Hal ini tidak berarti mengesampingkan peranan dan sumbangan anggota Gereja lainnya. Secara teologis para petugas pastoral Gereja dapat kita bedakan menjadi dua macam: para petugas pastoral non tertahbis dan para petugas pastoral tertahbis. Partisipasi dan pelayanan mereka dalam pelayanan pastoral Gereja dimaksudkan demi pembangunan Tubuh Kristus dan Kerajaan Allah di dunia dapat semakin berdayaguna dan berhasil guna; dan bukan malah, merugikan.

\section{Dasar Pelayanan Petugas Pastoral}

Konsili Vatikan IImengajarkan bahwa Gereja adalah Umat Allah. Menurut Congar (1965: 7-8), pandangan ini menekankan segi historis, segi dinamis/karismatis dan segi eskatologis Gereja. Sedangkan bagi Hans Kung (1967: 417) eklesiologi ini mengandung beberapa aspek penting yang perlu diperhatikan: 1) Gereja sebagai Umat Allah dan persekutuan umat beriman; 2) imamat umum kaum beriman; 3) Dimensi karismatis Gereja; 4) Arti Gereja setempat; 5) Jabatan gerejani sebagai pelayanan.

Aspek pertama dan keempat dalam eklesiologi Vatikan II ini menunjukkan nada-nada tertentu yang berbeda, namun bukan untuk dipertentangkan: di satu pihak ditekankan bahwa Gereja adalah umat beriman yang terhimpun sekitar Ekaristi (SC 41; 47; LG 11; CD 30; AG 36; PO 5; KHK kan. 1246-1247). Di lain pihak Konsili juga mengatakan bahwa dasar pemersatu umat Allah adalah Sabda Allah yang hidup (PO 4; DV 21; LG 25; AG 20), sehingga Gereja adalah umat beriman yang terhimpun berdasarkan sabdaAllah. Kedua hal ini perlu dimengerti dengan tepat agar tidak terjadi pertentangan di antara umat Allah ataupun adanya anggapan yang tidak tepat: adanya Gereja "kelas dua".

Sedangkan aspek kedua, ketiga dan kelima sangat menekankan kesamaan martabat di antara para anggota melalui pembaptisan, sekaligus keanekaragaman fungsi dan pelayanan setiap anggotanya berdasarkan karisma yang mereka terima dari Allah (1Kor 12:1-11). Aspek ini menunjukkan dengan jelas segi dinamis dan karismatis Umat Allah.

\section{Dasar Pelayanan Petugas Pastoral Non Tertahbis: Sakramen- sakramen Inisiasi dan Kebutuhan Gereja Setempat}

\section{Tugas Dan Tanggung Jawab Dari Sakramen Inisiasi}

Keanggotaan secara penuh dalam Gereja diberikan melalui sakramen Inisiasi. Sakramen ini terdiri dari dua sakramen pokok: sakramen 
pembaptisan dan sakramen penguatan. Keduanya berbeda, namun secara serentak mengungkapkan satu misteri penebusan Kristus. Pembaptisan berhubungan dengan misteri Pentakosta Kedua sakramen ini membawa umat beriman kepada Ekaristi, puncak dan penyempurnaan sakramen lainnya. Keanggotaan dalam Gereja terutama diterima seseorang dalam sakramen pembaptisan. Sakramen ini memberi aspek eklesial dan personal pada penerimanya. Kedua aspek di atas tidak terpisahkan, tetapi dihubungkan secara organis. (Dister, 2004: 381).

Dalam sakramen pembaptisan, seseorang dipersatukan dengan Gereja dan menjadi anggota Gereja (aspek eklesial). Keanggotaan ini memberinya "meterai suci" yang bersifat permanen, tak-terhapuskan, spiritual dan melekat dalam diri orang itu, sekaligus memberinya keśamaan martabat dengan anggota Gereja lainnya (LG 32).

Persatuan dengan Gereja - juga misteriNya - berarti juga persatuan dengan Kristus dan misteriNya. Hal ini berarti bahwa seseorang mengalami Kristus dan dipanggil untuk menjadi serupa dengan Kristus. Dengan demikian keanggotaan dalam Gereja mengandung di dalamnya suatu tugas: untuk bertumbuh dalam keserupaan dengan Kristus. Persatuan dengan Kristus sekaligus tugas untuk menyerupai Kristus merupakan aspek personal sakramen pembaptisan. Segi pengudusan diri ini bersifat tidak permanen, dapat hilang (tidak efektif) karena dosa. Akan tetapi pengudusan diri ini diefektifkan dengan penganugerahan rahmat Roh Kudus seperti yang dikehendakiNya (1Kor 12: 7-11).

Persatuan dengan Kristus, satu-satunya Iman sejati, berarti juga menjadi peserta dalam imamatNya (Dister, 2004: 382). Oleh karena itu dari kodratnya Gereja, Umat Allah adalah komunitas imamat (1Ptr 2:9-10). Gereja, Tubuh Kristus mewarisi imamat Kristus ini. Dengan demikian dapatlah dikatakan bahwa seluruh anggota Gereja, melalui pembaptisannya, mengambil bagian dalam imamat Gereja sekaligus imamat Kristus sendiri. Partisipasi ini disebut imamat umum kaum beriman.

Partisipasi dalam imamat Kristus mengandung arti juga partisipasi dalam misi pelayanan-Nya. Partisipasi ini juga merupakan bagian dari proses pengudusan diri untuk menyerupai Kristus. Oleh karena itu setiap anggota Gereja dalam pembaptisan menerima juga tanggung jawab, wewenang, kewajiban dan hak untuk mengambil bagian dalam misi pengudusan dan pelayanan Kristus dalam komunitas beriman. Partisipasi 
ini harus dilaksanakan secara aktif dalam kehidupan Gereja menurut karisma masing-masing (Jacobs, 1970: 234).

Pembaptisan saja belum lengkap tanpa menerima sakramen penguatan. Penguatan melengkapi pembaptisan. Dengan penguatan seseorang sungguh-sungguh bersatu dengan Kristus dan Gereja-Nya; ia menjadi anggota Gereja secara penuh (LG 11).

Dengan pembaptisan seseorang pertama-tama menjadi anggota Gereja dan di dalam Gereja ia dipersatukan dengan Kristus sekaligus lahir kembali menjadi anak Allah. Dengan penguatan seseorang sungguhsungguh bersatu dengan Kristus dan diikat secara lebih sempurna dalam Gereja serta menerima anugerah Roh Kudus secara khusus sehingga menjadikan dirinya sebagai anggota Gereja yang dewasa dan diutus untuk menjadi saksi Kristus yang sejati (Dister, 2004: 384). Dan hanya dalam rangka inilah tugas dan tanggung jawab yang diterima dalam pembaptisan dapat dimengerti dengan lebih baik. Pembaptisan memberi seseorang tugas dan tanggung jawab; ambil bagian dalam misi dan pelayanan Kristus di dalam Gereja-Nya. Dengan demikian menjadi jelaslah bahwa pembaptisan merupakan dasar bagi imamat umum. Akan tetapi tugas ini menjadi lebih jelas bagi seseorang yang menerima sakramen penguatan. Sakramen penguatan memberikan kepenuhan bagi imamat umum dalam partisipasinya di dalam misi dan pelayanan Gereja (Dister, 2004: 385).

Jadi sakramen-sakramen Inisiasi memberi tugas dan tanggung jawab untuk berpartisipasi dalam misi dan pelayanan Gereja di dalam hidup Gereja. Tugas dan tanggung jawab yang diterima dalam sakramensakramen Inisiasi merupakan sumber dan dasar bagi setiap umat beriman dalam mengambil bagian dalam misi dan pelayanan Gereja. Dari sinilah para petugas pastoral non tertahbis mendapat dasar (raison d'etre) pelayanan mereka dalam pelayanan pastoral Gereja. Meskipun demikian perlulah disadari bahwa tugas dan tanggung jawab itu berlaku bagi seluruh umat beriman; termasuk juga para petugas pastoral tertahbis dan umat beriman non petugas pastoral.

Lebih lanjut melalui berbagai pernyataannya Konsili menegaskan bahwa sakramen pembaptisan merupakan dasar partisipasi kaum beriman dalam misi dan pelayanan pastoral Gereja

“... umat beriman, yang digabungkan dengan Kristus oleh permandian, dilantik menjadi umat Allah dan mengambil bagian atas caranya dalam tugas Kristus sebagai iman, nabi dan raja, lalu 
menjalankan perutusan seluruh umat Kristen dalam Gereja dan dalam dunia sesuai dengan tanggungannya."(LG31)

“... tidak ada satupun anggota, yang tidak mempunyai bagian dalam perutusan seluruh Tubuh. Tiap anggota harus menguduskan Yesus dalam dirinya, dan harus memberi kesaksian tentang Yesus dengan Roh kenabian."(PO 2)

"Awam siapapun, yang dihimpun dalam umatAllah dijajarkan dalam satu Tubuh Kristus di bawah satu Kepala, sebagai anggota yang hidup dipanggil untuk menyumbangkan seluruh tenaganya, yang diterima karena kemurahan Pencipta dan rahmat Juru selamat, bagi pengembangan dan pengudusan Gereja yang berkesinambungan. Maka kerasulan awam adalah peran serta dalam perutusan penyelamatan Gereja. Untuk kerasulan ini semua orang ditugaskan Tuhan sendiri, lewat pembaptisan dan penguatan."(LG 33)

"Para awam yang mengambil bagian dalam tugas Kristus sebagai iman, nabi, dan raja, menjalankan peranannya dalam perutusan seluruh umat Allah di dalam Gereja dan di dalam dunia."(AA2).

Dengan demikian, Konsili suci menegaskan bahwa sakramen pembaptisan dan sakramen penguatan merupakan dasar teologis yang sah bagi pelayanan para petugas pastoral non tertahbis di dalam Gereja.

\section{Kebutuhan Gereja Setempat}

Sakramen-sakramen inisiasi merupakan dasar bagi para petugas pastoral non tertahbis untuk berpartisipasi dalam pelayanan pastoral Gereja. Pendasaran ini dapat lebih dipertegas dengan melihat konteks Gereja setempat: kebutuhan dan situasi kongkrit Gereja Setempat atau Gereja lokal.

Sakramen-sakramen Inisiasi - terutama sakramen pembaptisandi samping memberi tugas dan tanggung jawab kepada umat beriman untuk berpartisipasi dalam misi dan pelayanan Gereja juga memberikan kepada mereka hak untuk menerima dari para Gembala rohani bantuan dari khasanah rohani Gereja, terutama dari SabdaAllah dan sakremen-sakramen (KHK 213). Kalau pelayanan pastoral Gereja tidak dapat terlaksana dengan baik, maka Gereja setempat harus mengusahakannya sehingga 
kebutuhan rohani dan kesejahteraan jemaat dapat terpenuhi sebagaimana dilakukan oleh para rasul dahulu (Kis 6: 1-8).

Akan tetapi pada kenyataannya sebagian terbesar umat Katolik Indonesia tidak dapat menerima dan menikmati hak mereka untuk mendapatkan pelayanan pastoral, meskipun mereka punya hak. Hal ini kiranya disebabkan oleh: pertama, terbatasnya jumlah tenaga para Gembala rohani (petugas pastoral tertahbis, khususnya para iman); kedua, jumlah umat beriman yang membutuhkan pelayanan mereka sangat besar atau banyaknya jumlah kelompok basis yang tersebar di Indonesia (Sidang Agung Gereja Katolik Indonesia, 2000: 18). Di samping itu situasi geografis Indonesia kerap kali menyulitkan, bahkan menghambat pelayanan para Gembala rohani. Melihat keadaan di atas kiranya pelayanan pastoral Gereja Indonesia kurang memadai dan mencukupi bila hanya mengandalkan para Gembala rohani saja; karena dengan mengandalkan pelayanan para Gembala rohani saja akan dapat menghambat bertumbuh dan berakarnya Gereja sebagai komunikasi iman di Indonesia (Coomans, 1976: 79).

Realitas kongkrit Gereja Indonesia, khususnya Gereja Setempat, ini mendesak dan memotivasi lahir dan hadimya pelayanan petugas pastoral non tertahbis di dalam pelayanan pastoral Gereja setempat. Di samping Konsili Vatikan II sendiri memungkinkan munculnya pelayanan mereka. Dengan demikian sangat diharapkan kehadiran mereka akan menjadi bantuan besar bagi pembangunan Gereja setempat sebagai komunikasi iman: umat beriman dapat menerima dan menikmati kekayaan khasanah rohani Gereja secara lebih teratur.

Di samping situasi kongkrit dan kebutuhan Gereja setempat akan kehadiran para petugas pastoral, biasanya kehadiran dan pelayanan mereka masih perlu dipertegas dan diteguhkan oleh pejabat Gereja setempat. Peneguhan ini dapat berupa pengangkatan atau pelantikan oleh pejabat Gereja setempat (Uskup atau Iman). Hal lain yang tak kalah pentingnya adalah pemilihan dan kepercayaan yang berasal dari umat setempat yang kemudian dapat ditandaskan dengan pelantikan, pemberian mandat oleh pejabat Gereja setempat.

Dengan demikian dasar pelayanan para petugas pastoral non tertahbis adalah imamat umum yang mereka terima sebagai dasar teologis serta situasi kongkrit Gereja setempat: kebutuhan akan kehadiran para petugas pastoral non tertahbis agar kebutuhan jemaat dapat terpenuhi, penerimaan dan pelantikan oleh pejabat Gereja setempat. 


\section{Dasar Pelayanan Petugas Pastoral tertahbis: Tahbisan Suci}

Para petugas pastoral tertahbis adalah para Uskup, para Iman dan para Diakon. Pembahasan ini membatasi diri hanya pada para Iman dan para Diakon saja.

Pembaptisan menyatukan semua dan setiap orang dengan Kristus dan Gereja-Nya, menjadi anggota umat Allah, menerima martabat anakanak Allah, mengambil bagian dalam misi dan pelayanan Kristus dalare: Gereja-Nya, sekaligus mengambil bagian dalam misi dan pelayanan Gereja. Partisipasi dalam perutusan dan pelayanan ini diperjelas dalam sakramen penguatan. Dengan demikian, melalui pembaptisan, semua anggota umat Allah (baik tertahbis maupun non tertahbis) mempunyai kesamaan dalam martabat dan kegiatan umum dalam membangun Tubuh Kristus (LG 32), dan memiliki kesatuan dalam perutusan (AA 2). Jadi dalam hal ini tidak ada perbedaan di antara mereka.

Namun demikian dalam menjalankan misi dan pelayanan GerejaNya di dunia, Kristus mengadakan berbagai jabatan dan menunjuk orangorang tertentu dari antara umatNya untuk suatu tugas khusus demi kepentingan seluruh GerejaNya dan untuk mewakiliNya di dunia (LG 18, LG 32, PO 2).

Kelompok khusus itu dipilih Kristus untuk menerima jabatan dan tugas tertentu dalam Gereja: Uskup, Imam dan Diakon. Mereka ini menerima jabatan dari Kristus sendiri melalui wakilNya dalam pentahbisan dengan menumpangkan tangan (LG 21, LG 29, PO 2). Penumpangan tangan dalam pentahbisan inilah yang merupakan dasar teologis bagi pelayanan para petugas pastoral tertahbis.

Pentahbisan dengan menumpangkan tangan ini menjadikan mereka mengambil bagian di dalam imamat Kristus secara istimewa (PO 5); berbeda dengan partisipasi dalam imamat Kristus melalui imamat umum: "berbeda hakekat dan tidak hanya menurut tingkat saja"(LG 10). Meskipun demikian keduanya merupakan partisipasi dalam satu imamat Kristus atas caranya yang khas (LG 10). Perbedaan ini timbul "karena tugas masingmasing"(LG 13); suatu perbedaan yang secara hakiki bersifat fungsional (Jacobs, 1977: 358). Bukan suatu perbedaan dalam martabat.

Penumpangan tangan dalam pentahbisan berarti pertama-pertama pengangkatan ke dalam fungsi; bukan suatu penambahan martabat dalam diri mereka. Mereka tidak ada di atas yang lain, mereka mempunyai martabat yang umum dan tidak ada perbedaan dengan anggota umat Allah 
lainnya. Sebaliknya mereka diberi suatu fungsi khusus yang penting di dalam umat Allah yang sudah dikuduskan oleh Allah. Mereka berpartisipasi dalam Kristus dengan cara yang serupa dengan umat beriman yang lain, yakni: sebagai anggota Gereja. Mereka adalah anggota khusus yang secara fungsional dan menurut fungsinya mereka mengambil bagian dalam hidup Kristus (Jacobs, 1977: 358-364).

Selanjutnya, kiranya perlu diterangkan perbedaan 'hakekat" antara imamat jabatan dan iman umum: yang pertama adalah suatu fungsi dan yang kedua adalah martabat, sesuatu yang sama sekali lain daripada fungsi. Imamat umum tidak boleh dipandang sebagai suatu fungsi atau jabatan kaum awam; malahan imamat umum tidak boleh dipandang sebagai suatu imamat disamping fungsi imamat jabatan. Imamat jabatan tidak mempunya duamacam imamat; akan tetapi ia melaksanakan imamat umumnya dengan menjalankan fungsinya sebagai pejabat hirarkis.

Dari lain pihak jelas juga bahwa imamat umum tidak boleh disimpulkan dari fungsi jabatan atau dipandang sebagai perluasan dari imamat jabatan. Justru karena berbeda secara hakiki, maka imamat jabatan adalah lain, juga sebagai partisipasi dalam imamat Kristus. Imamat jabatan secara fungsional berpartisipasi dalam imamat Kristus, bukan sebagai orang perseorangan tetapi sebagai petugas. Sedangkan imamat umum adalah partisipasi dalam imamat Kristus sebagai martabat pribadi orang beriman Kristiani (Jacobs, 1977: 364-368).

Imamat umum dan imamat jabatan berbeda, namum keduanya saling terarah satu kepada yang lainnya (LG 10). Lebih lanjut Konsili mengatakan: "Imamat jabatan diperuntukkan bagi umat Allah: mereka ada dalam Gereja "demi saudara-saudara mereka" (LG 13), " melayani saudara-saudara mereka”(LG 18), “diangkat bagi yang lain"(LG 32).” Dengan demikian umat Allah dan keselamatannya merupakan tujuan bagi adanya imamat jabatan dalam Gereja; hirarki adalah sarana untuk mencapai tujuan itu.

Gagasan pelayanan ini dengan jelas dinyatakan Konsili dalam Lumen Gentium 24: "Tugas yang diserahkan Tuhan kepada Gembala umatNya itu merupakan pengabdian dalam arti sesungguhnya, yang di dalam Alkitab dengan tepat disebut diakonia atau pelayanan." Dan pelayanan ini pulalah yang merupakan segi hakiki dari imamat jabatan.

Namun perlu diperhatikan perbedaan antara pelayanan hirarki dan pelayanan Gereja sebagai keseluruhan. Pelayanan Gereja sebagai keseluruhan langsung terarah kepada dunia (AG 12; UR 20), sedangkan 
pelayanan hirarki merupakan pertama-tama suatu pelayanan sebagai pelaksanaan imamat umumnya dengan menjalankan pelayanan itu di dalam Gereja. Dan hal inilah yang menentukan tempat hirarki di dalam Gereja.

Dengan demikian imamat jabatan secara hakiki merupakan pejaytunan atau pengabdian. Apa yang menentukan hakekat jabatan adalah kedudukan fungsionalnya di dalam Gereja. Asas pokok jabatan gerejani adaiah tempatnya di dalam Gereja sebagai pelayanan(Jacobs, 1977: 368-37n)

Jadi, melalui pentahbisan dengan penumpangan tangan seseoraris menjadi anggota hirarki, petugas pastoral tertahbis. Melalui pentahbisan itu pula seseorang dipilih oleh Kristus sendiri untuk suatu tugas/fungsi pelayanan di dalam Gereja dan dibekali kuasa untuk menjalankan fungsi itu. Ia diangkat menjadi pelayan bagi yang lain. Pentahbisan dengan penumpangan tangan inilah yang menjadi dasar bagi pelayanan petugas pastoral yang tertahbis.

\section{Tujuan Pelayanan Petugas Pastoral}

Tujuan Pelayanan Gereja bukanlah untuk Gereja sendiri, akan tetapi untuk Kerajaan Allah (LG 9). Oleh karena itu setiap bentuk pelayanan dalam gereja-salah satunya adalah pelayanan pastoral-harus mengarahkan diri kepada tujuan itu. Tujuan pelayanan Gereja ini diungkapkan juga oleh Konsili: "demi pembangunan dan pengembangan seluruh Tubuh" (AA 2) dan "untuk mewartakan, menegakkan dan mewujudkan Kerajaan Allah di dunia" (LG 5, 9)

Pelayanan pastoral sebagai salah satu bentuk pelayanan intern di dalam Gereja mempunyai tujuan terutama demi pembangunan dan pengembangan seluruh Tubuh serta kesejahteraanNya. Dengan demikian, pelayanan para petugas pastoral merupakan suatu usaha untuk membangun, mengembangkan seluruh Tubuh dan kesejahteraanNya; suatu pelayanan terhadap persekutuan umat beriman untuk menumbuhkan dan mengembangkan iman mereka, memudahkan komunikasi iman dalam jemaat sehinggga umat beriman dapat membangun diri setiap hari: “di bawah gerakan Roh Kudus umat harus terus, tanpa henti-henti membaharui diri mereka"(LG9). Akhirnya melalui pelayanan para petugas pastoral Gereja seluruh umat beriman dapat bertemu dengan Allah Sang Pencipta, asal dan tujuan serta Sumber keselamatan manusia (Jacobs, 1977: 373; Groenen, 1987: 20-21). Itulah yang menjadi tujuan pelayan-petugas pastoral dalam Gereja. 
Di samping tujuan mendasar, Konsili Vatikan II secara istimewa menyebutkan juga tujuan pelayanan para petugas pastoral tertahbis: "mewakili Kristus di dunia" (LG 11, 22, 27) dan "mempersatukan umat beriman dalam Kristus" (LG 21; 28; 32; OT 4; AA 2; PO 2). Dan dalam rangka inilah pelayanan mereka harus dimengerti (Kloppenburg, 1974: 271). Sejalan dengan hal ini dan dalam batas-batas tertentu, para petugas pastoral non tertahbis kiranya juga memiliki tujuan pelayanan: mempersatukan umat beriman dalam Kristus (Hardawiryana, 1976: 4-6).

\section{Kesimpulan}

Gereja adalah penerus misi dan pelayanan Kristus, yaitu keselamatan umat manusia dan pembangunan Kerajaan Allah di dunia. Sedangkan semua bentuk pelayanan yang ada dalam Gereja merupakan partisipasi dalam pelayanan dan misi Gereja.

Salah satu bentuk pelayanan Gereja adalah pelayanan pastoral. Pelayanan ini dilaksanakan Gereja dalam dan melalui diri para petugas pastoral, baik petugas pastoral tertahbis maupun petugas pastoral non tertahbis. Keduanya memiliki dasar pelayanan yang berbeda, namun keduanya toh berpartisipasi dalam satu imamat Kristus dalam cara yang berbeda serta memiliki tujuan pelayanan sama. Para petugas pastoral non tertahbis mendapatkan dasar pelayanannya dari sakramen-sakramen Inisiasi, teristimewa s. pembaptisan, dan selanjutnya mereka diperteguh dengan pengangkatan atau penunjukan dan pelantikan oleh pejabat Gereja dan atau oleh umat beriman setempat. Sedangkan para petugas pastoral tertahbis mendapatkan dasar pelayanannya dari pentahbisan dengan penumpangan tangan oleh Uskup, sebagai wakil Kristus sendiri. Perbedaan ini pada dasarnya adalah suatu perbedaan fungsional dan saling terarahkan karena partisipasinya dalam satu imamat Kristus dan dengan tujuan pelayanan yang sama.

Perbedaan dalam dasar pelayanan itu membawa konsekuensi pada perbedaan ungkapan/bentuk pelayanan mereka dalam Gereja. Meski demikian perbedaan tersebutmemiliki tujuan pelayanan sama. Tidak jarang dalam praksis pelayanan pastoral mereka, perbedaan-perbedaan itu menimbulkan ketegangan di antara mereka sehingga menghambat pembangunan, perkembangan dan kesejahteraan seluruh Gereja. Ketegangan ini masih juga ditunjang oleh beberapa faktor, antara lain: pandangan klerikalisme yang masih nampak, kepribadian petugas pastoral 
dsb. Padahal kalau mereka sadar dan selalu ingat bahwa mereka bersama berpartisipasi dalam satu imamat Kristus, dimaksudkan agar saling terarahkan serta memiliki satu tujuan pelayanan, maka ketegangan di antara mereka tidak perlu terjadi dan mau tidak mau malahan akan mengz stk mereka kepada suatu kerjasama. Kerjasama ini mutlak perlu dan harus hidup di dalam pelayanan mereka agar pelayanan mereka dapat berhasil guna dan berdaya guna bagi kesejahteraan seluruh Gereja serta dapat mencapai tujuannya secara optimal (Macu, 1987: 92).

Kerjasama yang harus hidup dalam pelayanan mereka adalah kerjasama yang diagonal dan mutual dalam semangat dan suasana persaudaraan dan kerekanan. Untuk mewujudkan kerjasama seperti ini diperlukan iklim yang cocok serta waktu yang cukup panjang dan harus dimulai sekarang juga terutama dari pihak para petugas pastoral sendiri. Bahkan harus dimulai sedini mungkin: sejak mereka masih berada dalam jenjang pendidikan, sehingga kelak mereka sudah terbiasa untuk menjalin suatu kerjasama dalam menjalankan pelayanan pastoral Gereja. Inilah harapan yang perlu untuk selalu dipikirkan dan diwujudkan sekarang juga.

\section{DAFTAR PUSTAKA}

1983. Kitab Hukum Kanonik. Jakarta: Obor.

. 1993. Dokumen Konsili Vatikan II (R. Hardawiryana, penerjemah). Jakarta: Obor.

Congar, Yves. Januari 1965. "The Church: The People of God". Concilium. Januari 1965.

Coomans, M. 1976. “Awam Sebagai Pemimpin Ibadat.” Spektrum. No.1, tahun VI.

Dister, Nico Syukur. 2004. Teologi Sistematik 2. Yogyakarta: Kanisius

Gonzalez, Javier. 1998. Lay Ministries. San Juan: Life Today Publications.

Groenen, C. 1987. "Peranan Mereka Yang Ditahbiskan Pada Gereja Yesus Kristus. Orientasi Baru”. No. 1, tahun I, hlm. 
Hardawiryana. 1976. “Awam Pemuka Jemaat”. Spektrum. No. 1 tahun VII.

Jacobs, Tom. 1970. Lumen Gentium: Terjemahan - Introduksi Komentar I. Yogyakarta: Kanisius.

Jacobs, Tom. 1977. "Ministri in Vatican II and Post Conciliar Development. Asian Colloquium on Ministries in the Church". Pedro S. De Achutegui, ed., Manila: FABC.

Kloppenburg, Bonaventure. 1974. The Ecclesiology of Vatikan II. Chicago: Franciscan Herald Press.

Kung, Hans. 1967. The Church. London: Burn And Oates.

KWI, Komisi Karya Misioner dan Karya Kepausan Indonesia. Oktober 2007. "Laporan Penelitian Kelompok Basis Gerejawi (KBG) di Indonesia 2002-2004”. SAWI. No 20.

Macu, C. 1987. "Kerjasama (Ketegangan) Antara Petugas Tertahbis dan Tak Tertahbis. Orientasi Baru”. No. 1, tahun I.

Sidang Agung Gereja Katolik Indonesia, Panitia. 2000. "Gereja Yang Mendengarkan”. Jakarta: Panitia Sidang Agung Gereja Katolik Indonesia.

Threes WS. September 2001. "Ketombe di Tubuh Gereja". Utusan. No. 09, Tahun ke-51. 


\section{PERSYARATAN PENULISAN ILMIAH DI JURNAL JPAK WIDYA YUWANA MADIUN}

01. Jumal IImiah JPAK Widya Yuwana memuat hasil-hasil Penelitian, Hasil Refleksi, atau Hasil Kajian Kritis tentang Pendidikan Agama Katolik yang belum pernah dimuat atau dipublikasikan di Majalah/Jurnal IImiah lainnya.

02. Artikel ditulis dalam Bahasa Indonesia atau Inggris sepanjang 7500-10.000 kata dilengkapi dengan Ábstrak sepanjang 50-70 kata dan 3-5 kata kunci.

03. Artikel Hasil Refleksi atau Kajian Kritis memuat: Judul Tulisan, Nama Penulis, Instansi tempat bernaung Penulis, Abstrak (Indonesia/Inggris), Kata-kata Kunci, Pendahuluan (tanpa anak judul), Isi (subjudul-subjudul sesuai kebutuhan), Penutup (kesimpulan dan saran), Daftar Pustaka.

04. Artikel Hasil Penelitian memuat: Judul Penelitian, Nama Penulis, Instansi tempat bernaung Penulis, Abstrak (Indonesia/lnggris), Kata-kata Kunci, Latar Belakang Penelitian, Tinjauan Pustaka, Metode Penelitian, Hasil Penelitian, Penutup (kesimpulan dan saran), Daftar Pustaka

05. Catatan-catatan berupa referensi disajikan dalam model catatan lambung.

Contoh: Menurut Caputo, makna religius kehidupan harus berpangkal pada pergulatan diri yang terus menerus dengan ketidakpastian yang radikal yang disuguhkan oleh masa depan absolut (Caputo, 2001: 15)

06. Kutipan lebih dari empat baris diketik dengan spasi tunggal dan diberi baris baru.

Contoh: Religions claim that they know man an the world as these really are, yet they they differ in their views of reality. Question therefore arises as to how the claims to truth by various religions are related. Are they complementary? Do they contradict or overlap one another? What -according to the religious traditions themselves-is the nature of religious knowledge? (Vroom, 1989: 13)

07. Kutipan kurang dari empat baris ditulis sebagai sambungan kalimat dan dimasukkan dalam teks dengan memakai tanda petik.

Contoh: Dalam kedalaman mistiknya, Agustinus pernah mengatakan "saya tidak tahu apakah yang saya percayai itu adalah Tuhan atau bukan." (Agustinus, 1997: 195)

08. Daftar Pustaka diurutkan secara alfabetis dan hanya memuat literature yang dirujuk dalam artikel. Contoh;

Tylor, E. B., 1903. Primitive Culture: Researches Into the Development of Mythology,

Philosophy, Religion, Language, Ert, and Custom, John Murray: London

Aswinarno, Hardi, 2008. "Theology of Liberation As a Constitute of Consciousness," dalam Jurnal RELIGIONo. I, April 2008, hal. 25-35.

Borgelt, C., 2003. Finding Association Rules with the Apriori Algorthm, http:/hwww.fuzzi.cs.uni-magdeburg.de/-borgelt/aprioril. Juni 20, 2007

Derivaties Research Unicorporated. http//fbox.vt.edu.10021/business/finance/ dmc/RU/content.html.Accesed May 13, 2003 